\title{
Exploration of the Ideological and Political Education in Network Age
}

\author{
Fangqian Chen \\ Pingxiang University, Pingxiang, 337055, China
}

Keywords: Network Times, Ideological and Political Education, Challenge and Strategy

\begin{abstract}
The development of the Internet not only brings the development opportunity to the ideological and political education in Colleges and universities, but also brings some challenges. In today's society, how to deal with the opportunities and challenges brought by the Internet, has become a hot issue in the ideological and political education courses in colleges and universities. In this article, the author will mainly introduce the positive role of the ideological and political education in the network era and the challenges it faces, and put forward the corresponding countermeasures, in order to promote the development of Ideological and political education.
\end{abstract}

\section{Introduction}

The arrival of the Internet era not only brings opportunities to the development of the ideological and political education, but also brings some challenges to the development of the ideological and political education. Therefore, in order to grasp the opportunities brought by the Internet era, colleges and universities must take advantage of the advantages and characteristics of the network, and actively explore ways and means of the development of Ideological and political education, so as to provide power for the development of Ideological and political education.

\section{The positive role that the Internet age plays on the ideological and political education}

\section{The content of Ideological and political education is enriched in the Internet age.}

Now, with the development of the Internet, human society has entered the era of big data, which provides a large amount of information resources for the school's ideological and political education, and further enrich the content of ideological and political education in schools. In today's network, there are a variety of different values, outlook on life and culture, which makes the original boring ideological and political education content more substantial. Therefore, in the education process of Ideological and political in colleges and universities, we should make good use of information resources on the network, and blending into the Lenin Marx, Mao Zedong thoughts, Deng Xiaoping theory and three representatives of important ideas, to provide a broad thinking space for the students, so as to help college students establish a correct outlook on life and values, so that students can become a person useful to the country. Therefore, in the network era, the reform of Ideological and political education should keep pace with the times, and actively introduce relevant information on the network, so as to enrich the students' learning life and the teaching content of Ideological and political education.

\section{The innovation of the Internet age provides a new platform for the development of Ideological} and Political Education

With the development of science and technology and social progress, the traditional ideological and political education mode has been unable to meet the requirements of the times, and the innovation of network era can change the inherent mode of traditional ideological and political education, and provide a new platform for students, on this platform, students can carry on autonomous learning through the network electronic mail,weibo, BBS and network courses and other forms. In addition, the network platform can also shorten the distance between teachers and students, 
so that teachers and students can communicate through the network, which can help the teachers to find students' problems, and to take a certain method to correct it ${ }^{[1]}$.

\section{The equality and interaction of the Internet age can improve the students' acceptance level.}

Network platform has a certain degree of equality and interaction, the students can speak freely and without restriction in the network. In addition, they also can communicate with others through the network platform, and this exchange is equal and open. Therefore, using the network platform to carry out ideological and political education can improve students' acceptability. In the Internet age, the network's interactivity and equality do not have such a problem, the network can provide an equal platform for students and teachers to communicate ${ }^{[2]}$. In addition, the network can eliminate the concerns of blowing their cover for the students, in the network, students can publish their own comments, speak their true ideas, and the teacher make the right guidance just for these ideas, and therefore it will not involve other aspects of the problem. In this case, the exchange between teachers and students is the real heart and the exchange between the heart.

\section{The challenge to the ideological and political education in the Internet Age}

\section{The diversification of the Internet age will affect the students' values.}

The network is a place of multi-culture collection, here, no matter the culture is good or bad, they all exsit in a certain form, and deeply effect the formation of the students' value and the life outlook. In the process of Ideological and political communication, the traditional media such as newspapers, magazines and so on are checked at each level before the content to show in front of people, while the network is open and free, so that when some bad information is spread, the network has been difficult to control the situation ${ }^{[3]}$. These characteristics of the network has brought a certain challenge to the ideological and political education, which makes the network information out of the shackles of morality, and then affects the students' physical and mental health, but also seriously hindered the spread of the right ideas. In addition, because of more advanced information technology, the western countries occupy a dominant position in the network culture propagation, many unruly countries intent to use this advantage to accelerate the spread of capitalist ideology and effect the ideas of students. Moreover, the university students are in the developing period, any cultural form will cause the influence to its development, at the same time, the university student's ability to distinguish the ability is limited, the resistance ability is poor, if they do not grasp the moral direction, it will cause the serious consequence to their future.

\section{The rapid development of the Internet era to put forward higher requirements to the teaching staff}

In the Internet age, the current ideological and political education is lack of the ability to deal with the network information. When the students have some problems, the teacher can not use the correct method to solve the problem. Therefore, the rapid development of the Internet era has brought challenges to the ideological and political education workers in colleges and universities. In the network era, teachers must strengthen their own comprehensive quality, expand their knowledge, and master some computer technology, only in this way, the university teachers in the field of Ideological and political education can get a good development.

\section{The imperfection of network regulations causes the lack of students' network rationality}

Now, in the face of a large number of bad information on the network, the government does not have the appropriate regulations to regulate, which makes the students in the network era very easy to be affected by bad information, in order to get a real sense of achievement on the network, many students do not hesitate to waste a lot of money and time, which will have serious impact on the physical and mental health and the future of students ${ }^{[4]}$. In addition, some criminals are still on the 
Internet to spread a large number of pornographic and violent information, which will be a serious corrosion to the students' ideas.

Network is a virtual world, in the network world, because of poor self-control, lack of moral constraint, the physical and mental health of many students has been seriously affected, and even some students use their own computer expertise to attack the system, to implement the network crime, these are the negative impact of the unsound network regulations. Therefore, in order to give students a healthy network environment, the relevant personnel should increase the network supervision, and formulate corresponding laws and regulations, to eliminate the adverse effects of the network.

\section{Countermeasures of Ideological and political education in Network Era}

\section{Strengthen the construction of network ideological and Political Education}

In the network environment, to improve the students' comprehensive quality, we must establish a higher level of political theory, and be familiar with the law of Ideological and political work, but also more effective grasp of the network technology and the network culture characteristics, the teams who can carry out ideological and political education work on the network, have made important organization guarantee of Ideological and political education in the network era.

First, we must strengthen the theoretical culture and the improvement of the level of the ideological and political morality ${ }^{[5]}$. Network ideological and political educators must have a solid foundation of Marx's theory and a firm political belief, master a solid ideological and political education work theory, and be good at the use of Marxist position, viewpoint and method, analysis of the law, the principle and method of network ideological and political work, and constantly improve the level of theory, policy level and ideological and moral quality level.

Secondly, we must strengthen the cultivation of the network quality ${ }^{[5]}$. For the subject of Ideological and political education, the knowledge and ability of network technology, network media literacy and the technology idea of the network become the main body of education in the network era. Network ideological and political education subject should strengthen the training of network knowledge, set the students' Ideological and political education, information collection and dissemination of communication and network management in a body. Educators should adapt to the new network environment, and have the ability of corresponding network knowledge, improve their own network media literacy, cultivate excellent quality of information. They must have a keen awareness of information, and make full use of the network to capture and absorb the information, and to contact the ideological and political work. Have a strong ability to obtain information, information processing ability and the ability to transmit information, and to solve the problems in the network. Also a higher network language application ability is needed, they can create the correct network public opinion, and actively guide the educated in the use of network and receiving network information process, consciously accept the ideological and political education, improve their ideological and political theory level.

Finally, we must strengthen the cultivation of human knowledge ${ }^{[5]}$. Only on the basis of extensive knowledge, the innovative ideas can be formed, the innovative ideas are determined. This needs to understand the knowledge of political science, sociology, law, literature, journalism and communication, education, psychology and ethics, to form the knowledge structure more sharp. Expanding knowledge, improving their comprehensive quality, so that their knowledge level and ideological level is always at the forefront of the times, then the field of vision will be more open, more active thinking, to grasp the initiative of Ideological and political education innovation, to enrich the solid scientific and cultural knowledge and strong policy theory.

\section{Improve the students' ability of self control and distinguish}

In the process of Ideological and political education, the university should pay attention to cultivate students' moral quality, and further develop the students' net morality, improve their ability of self-restraint and distinguish ${ }^{[5]}$. In addition, colleges and universities should arrange the 
corresponding activities regularly to carry out patriotic education to students, so as to cultivate students' patriotism and historical mission, students can not only get the moral sublimation, but also to improve their comprehensive quality. Under the background of network era, the school can be targeted to open a number of specialized network ethics courses, so that the students can be through the way to promote the students' moral standards, and further improve the students' moral awareness, standardize the moral behavior of students. Finally, the university should strengthen the management of students, and formulate the relevant rules and regulations, and regulate the network behavior of students.

\section{Strengthen students' mental health education}

College Ideological and political education workers are the leading of students' Ideological and moral construction. In daily life, the ideological and political education workers should communicate with students, understand the real ideas, and open up the channels to the students according to their psychological characteristics, so as to help students establish a correct outlook on life and values, and then develop a sound personality. In addition, teachers should encourage students to self-reflection and education, but also to encourage students to help each other, in order to create a positive atmosphere of life, so that students can build their own personality in a healthy and harmonious environment.

\section{Combined ideological and political education with network technology}

Colleges and universities should make full use of the advantages of the network to build a network platform of Ideological and political education, and to promote the ideological and political education of the network. First of all, the school can use the convenience of the campus website to open a column on the ideological and political education, and put some positive and healthy cultural information to the website, in order to enhance the students' Ideological and political awareness; Secondly, the schools should encourage teachers to carry out online teaching, and the opening of the corresponding psychological counseling platform, so that teachers can communicate with students on the platform; in addition, the school should be based on the interest of the network to organize some cultural activities, and put the correct outlook on life and values into activities, so as to improve the students' Ideological and moral education, so that students feel the significance of Ideological and political education; Finally, the school can actively develop some software about the ideological and political education, and encourage students to actively download the use, so that the ideological and political education can be integrated into the daily lives of students, so that students can be aware of the ideological and political education at any time.

\section{Conclusions}

But above all, in the network era, the ideological and political education in Colleges and universities faces both opportunities and challenges. In this case, the university should start from the characteristics of students, from themselves, to build a positive network ideological and political education platform for students.

\section{References}

[1] Luo Yuanyuan. University Recessive Ideological and political education in the network era. Jianghan Tribune,2012(12):31-33.

[2] Ren Xiaoyan, Fu Peishan. Dilemma, attribution and transcendence of Ideological and political education in the network era. Realistic,2013(3):73-77

[3] Li Jinghua. Discuss the position of the ideological and political education in the network Age. Journal of Henan Normal University (Philosophy and Social Science Edition), 2011,38(1):259-261. 
[4] Geng Xiangkui. Innovation of college students' Ideological and political education in the Internet Age. Ideological Education Research, 2013(10):44-47

[5] Chen Fangqian. The effectiveness analysis of ideological and political education and innovation Ideological in Contemporary Colleges and Universities[M]. Jinlin University Press, 2015, (5):172-173 